\title{
The State of the Hungarian Pig Industry Following Accession to the European Union and its Impacts (2004-2013)
}

\author{
Mrs. Belane Vinkler, PhD student \\ Budapest Metropolitan University, Heller Farkas Faculty of Tourism and \\ Economy, Institute of Economics, Hungary
}

doi: 10.19044/esj.2017.v13n1p1

URL:http://dx.doi.org/10.19044/esj.2017.v13n1p1

\begin{abstract}
The present paper aims to describe the period following Hungary's accession to the European Union, its impacts on the country's economy with special focus on the state of the national pig industry. After the EU accession, predictability within the industry became history; even the domestic prices of fodder are dependent on global market prices. A significant part of animal farmers do not own land and grow their fodder needs on rented plots or solve this problem by purchasing from the market. However, the constant fluctuations in the currency exchange rates and mercantile exchange speculations also influence prices and the income producing capability of animal farming. It is not surprising that because of the declining purchasing prices of pork and the unpredictability of fodder prices many farmers are considering giving up production.

These days the change in external conditions is not only a constant phenomenon, but is showing a quickening trend posing a challenge to all countries. If they wish to stay successful in the long term, they have to take into account the internal and external changes alike, which directly or indirectly will have an impact the operation of the given country. Globalisation has become a fairly popular and often-used term to describe the processes inherent that make a significant effect on the labour market as well.

It is important to assist in the stabilisation of the existing and operating pig farms so that we can utilize the potentials inherent in them.

In this part (part I.) the pig industry and the situation changes of the pig population will be described until 2004-2013 period. In the next part (part II.) the structure of Hungarian pig industry and pork in the Hungarian pig sector until 2007-2013 period will be described.
\end{abstract}

Keywords: EU, pig industry sector, purchasing prices, competitiveness, pork chain 


\section{Introduction}

The priorities of Hungarian agrarian policy are to ensure the food and raw material supply for the population, to continuously improve the standard of living of workers employed in the different sectors of agriculture, to maintain and increase the competitiveness of different sectors on international markets, and to protect and preserve the local environment and its natural elements (Buday \& Sántha, 2001).

Popp (2004) claims that the impact of the liberalisation of trade made on the environment can be affected by appropriate regulation methods. The WTO agreement on plant and animal health measures aims to prevent individual governments from using the appropriate level protection of plants, animals and people (belonging to a country's sovereignty) for the purposes of protectionist trade.

Considering the environmental impact of animal husbandry, the volume of Hungarian livestock - even in its heyday of the 1980s - did not reach $50-60 \%$ of the EU's area unit livestock standard and since then the continuous decline has not stopped, but the livestock fell a further $40 \%$. The stock of implements owned by livestock farmers is in a critical state, they are not concerned with environmental impacts like the treatment of manure, they are unable to modernize production due to lack of capital, and are simply struggling for their daily survival and maintenance of their business. On the other hand, for the large pig farming plants, the introduction of modern technology and the maximization of animal capacity (1,000 hogs) ensure a competitive edge (Sántha, 1999).

Popp (2004) argues that the fall in the average sale price was a consequence of the adverse weather conditions and drought of 2003, and due to an increase in fodder prices carried over to 2004, affected the cost per tonne of pig fattening which in turn affected the profitability of businesses. The 2,000 Ft/animal subsidy linked to the observation of livestock breeding regulations did not help pig farming either. The EU regulations on animal welfare and environment protection resulted in higher investment costs which, in turn, increased the costs of production leading to further problems in the export and import markets of pork.

Another factor hindering competitiveness is that the organisation and concentration level of the pork chain lags far behind the rest of the pork producing member states. In order to improve the competitiveness of the pig farming sector, the entire structure has to be revamped. Presently, the profitability of businesses involved in pig farming is very low, so an increase in the volume of livestock cannot be expected.

According to the EU regulations on animal welfare the sectors of animal husbandry had to meet very strict requirements both in environmental protection and animal welfare including the rules on standard space for 
animals and a more rigorous inspection routine of animal farms even between 2005 and 2010. The animal welfare subsidy provides support for farmers prepared to keep the strict regulations. It requires a 5-year commitment and is meant to compensate for the expenses incurred and the lost income with an annual subsidy of 500euro/ large animal.

The liberalisation of international trade has a definitive impact on the import of pork as the meat originating from the USA are more expensive on the markets of the European Union and its price is normally determined by the fluctuation of US dollar/ euro exchange rate and the related production costs. In the near future, a change is expected in the geographical allocation of fodder feeding sectors both in the EU and at global level and pig farmers are striving to locate their plants closer to the areas of fodder production.

After 2004, the appearance of dumping price meat made an adverse impact on the domestic market. The price of corn directly affected fodder prices causing their increase which, in turn, resulted in the growth of rape production. The leaders on the domestic pork market (PÁIR) slaughtered 230,000 hogs in 2005, and sold between 20 and $60 \%$ of cut meat on the home market while the rest was exported. Non-market leaders sold only on the home market. Their sales income accounted for $80-90 \%$ of the total sales of half pigs. Meat processing plants usually have their own retail shops accounting for $5-10 \%$ of total sales turnover.

According to the studies of Varga et al. (2007), we have age-old traditions in the domestic raising and processing of pork. However, Hungary contributes only $0.5 \%$ to the global production and shares $2.5 \%$ in the EU's production volume. Among the 10 countries acceding in 2004, Hungary ranks second following Poland the leader. In 2002, before the accession to the EU, Hungary was a net pork exporter. In the following three years, in order to satisfy the growing domestic demand and to keep the export markets, Hungary was forced to significant import of both livestock and slaughtered pigs and consequently by 2004, the year of EU accession, it became a net importer in livestock both in terms of volume and value (Varga, Tunyoginé \& Mizik, 2007).

In importing pork we were confined to settle for the poorer quality and cheaper varieties. In the midst of the increasing commercial competition quality expectations were disregarded and the old proverb "cheap meat produces thin broth" was not respected by the customers. The domestic meat processing plants could not compete in price with the large food retail chains. They very rarely contract with local producers and would rather make their meat product purchases with their traditional foreign suppliers. A way to overcome this problem could be to enforce the quality requirements of a Foodstuff Register approximating the European normative regulations (Popp \& Potori, 2009). 
In this period (in 2006), $75 \%$ of pork export was transported by road and $22 \%$ by rail with only $3 \%$ transported by air (Kartali, 2008).

After the economic and political transition of the early 1990s, we were left behind in the competition and the animal husbandry sector hit its historical low. However, by 2008, we reached 1.25 million heads after 60 years in a peaceful period, but would be able to keep up to 3 million heads of livestock (Kralovánszky, 2009).

In the opinion of Popp and Potori (2009) the Hungarian purchasing prices are mainly determined by the prices in Germany and Holland. In early 2009 , the domestic purchasing price of pigs exceeded the prices of foreign countries by $20 \%$, which proves that it was more economical to import livestock and pork into Hungary even accounting for the significant transportation costs. However, the impact of the constant fluctuations of the exchange rate between the forint and the euro rendered the import of livestock unprofitable since the transport costs that were only 25 forints per live weight in 2008, increased to 45 forints per live weight by 2009. According to the authors cited above, because of the steady decline of domestic pig livestock, local food processing plants were forced to import pork. In 2008, the volume of import amounted to 72 thousand tonnes exceeding the figure of the previous year by $9 \%$, which stood at 66 thousand tonnes in 2007. 35\% of Hungary's exports (35 thousand tonnes) were directed to Romania.

In 2007, global production of pork amounted to 103 million tonnes and both the OECD and FAO predict a further growth till 2017 that could reach 125 million tonnes. About $80 \%$ of global output will be provided by China, the EU and the USA. It is also predicted that in the period between 2009 and 2017, China's share will increase to $49 \%$ while the production ratio of the EU27 will decrease from $20 \%$ to $18 \%$. On a global scale there has been no major modernisation of meat production in the past period. Hungary has recently embarked on the introduction of high vitamin content fodder technologies. The population has become more aware of "healthy nutrition" and this could result in an increased demand for fish, organic produce and seafood. These new trends may provide a break-out point for the Hungarian meat industry although they incur significant investments and innovation.

A definite trend of concentration and specialisation has started in the field of processing, and raw material production in the pig farming sector. Producers formed Purchasing and Sales Organisations (BÉSZ) whose members by acting jointly strive to corner a larger volume on the market. However, certain statistical figures suggest a growing presence of the grey economy in the whole pork chain. Pig farmers are also responsible for the existence of the grey economy since the pigs disappearing through the illegal sales channels must be somewhere in the system as evidenced by the statistical figures following below: 
- in 2007, the Fat Stock and Meat Product Council (VHT) according to its own statistics facilitated the purchase of 3.8 million hogs, whereas the data of the Agrarian Research Institute (AKI) confirm the slaughter of 4.76 million heads,

- in 2008, the AKI figures claim 4.3 million slaughtered hogs in Hungary, while the VHT data mention only 3.15 million.

Varga et al. (2007) point out that there are great differences between the market leader livestock importing slaughterhouses. Some of them import only $10 \%$ of the stock, while others purchase almost $40 \%$ from EU member states or other countries. In general, slaughterhouses and meat processing plants strive to purchase domestically raised pigs and only supplement them from import. However, it is simply necessary because of a shortage of domestic stock material.

When purchasing locally raised slaughter pigs, the annual contracts stipulate the quality, quantity and the payment requirements. It would be important to implement a more efficient vertical integration of the actors which, of course, requires an adequate funding. In their activities, slaughterhouses took measures to secure the necessary pig stock by contracting for fattening. As a first solution they buy the farrows and supply the necessary fodder (then buying the slaughter pigs at cost price). Cooperation with pig farmers is very important for the slaughterhouses in order to secure the supply of stock for their use. A second solution is contract fattening, which is more beneficial to the slaughterhouses as they only purchase the farrows and the rest of the expenses are met by the producer. They buy the slaughter pigs at a market price deducting the farrows' price and the interest rate so they maintain a lower risk and can achieve lower input costs than the national average.

Producers' decisions are greatly affected by their liquidity position. Due to a rampant shortage of stock material, the decline in livestock volume and the price increase of stock imported from the EU, a harsher price competition between slaughterhouses can be expected in Hungary. Domestic prices changes of pigs are decisively influenced by the prices in EU member states and domestic prices constantly follow the changes in EU average prices. Consultation with the suppliers is necessary due to the constantly changing prices as the volume of locally produced stock shows a steady decline. Slaughterhouses have no information on the prices of their competitor meat processing plants, and can only draw conclusions from the changes in consumer prices. The cheap and poor quality pork imported by the large retail chains forces down the purchasing price of the higher quality locally produced stock. Consequently, the sale price of pork produced in Hungary is also affected by the prices of imported stock. 
In the period between 2008 and 2014, consumption of pork in the EU27 member states is expected to reach $42-43 \mathrm{~kg} /$ capita. In Hungary, according to the figures of the Central Statistical Office, the per capita pork consumption amounted only to $27.9 \mathrm{~kg}$ in 2006, heavily influenced by the domestic income levels. (AK II System)

The domestic price level of pork exceeded the world market price by $11 \%$, when the impact of world market prices to the EU pork prices stood at $51 \%$ on average. OECD-FAO Dataset 1970-2015, OECD, 2006. (Retrieved from: http://stats.oecd.org/wbos/viewhtml.aspx?QueryName=237\&QueryType=Vi ew\&Lang=en)

According to forecasts pork production in the EU will grow at a slower pace in the period between 2008 and 2015 than it did in the previous decades. The statistics of the European Commission show that pork production of the EU27 in 2008 decreased by $1.3 \%$ compared to the previous year. The Commission predicts that the EU27 pork output may only reach a $1.7 \%$ growth in the period between 2008 and 2015. (European Commission, 2009a)

\section{Trends in the Hungarian pig farming sector 1990-2014}

When examining the state of the Hungarian pig livestock in the given period, it can be concluded that the sectors of animal husbandry were the biggest losers suffering from a general setback of agricultural production. From the 1990s to the present, the production figures of pig farming within the whole animal husbandry sector show a steady decline in the past 25 years that is more than two decades following the economic-political transition. This chapter of the paper describes the transformation of the domestic pig market between 1990 and 2014. The aim was not to give a detailed analysis of the sector, but to depict the general context against which my findings could be highlighted. A brief introduction is presented on the transformation of the sector, the decline in pig livestock, the structural transformation within the sector, the changes in demand, the trends in international trade, and finally the state regulation of the sector.

The chosen time interval clearly shows that the volume of the present pig livestock is the lowest of the past 70 years since the end of World War 2. In the period between 1990 and 2014, the Hungarian pig livestock was characterised with large scale fluctuation well attested by the figures of Table 1. At the start of the economic-political transition, in September 1990, the Hungarian pig livestock numbered 8 million, but by 2014, it fell back to a mere 3.136 million, which is 5 million head drop in livestock compared to 1990 . The numbers at the end of 1994 stood at close to 4.4 million heads which was the lowest point with only $45 \%$ of the stock registered in 1990 . Although by the end of 2002, this figure climbed back to over 5 million (which is nearly 
$56 \%$ of the 1990 volume), due to significant changes in the period after that, the pig and sow livestock started to decline again. Unfortunately, there is hardly any grunting coming from the pigsty: the Hungarian pig livestock shows a drastic decline.

Table 1 gives a good illustration of the changes in pig livestock.

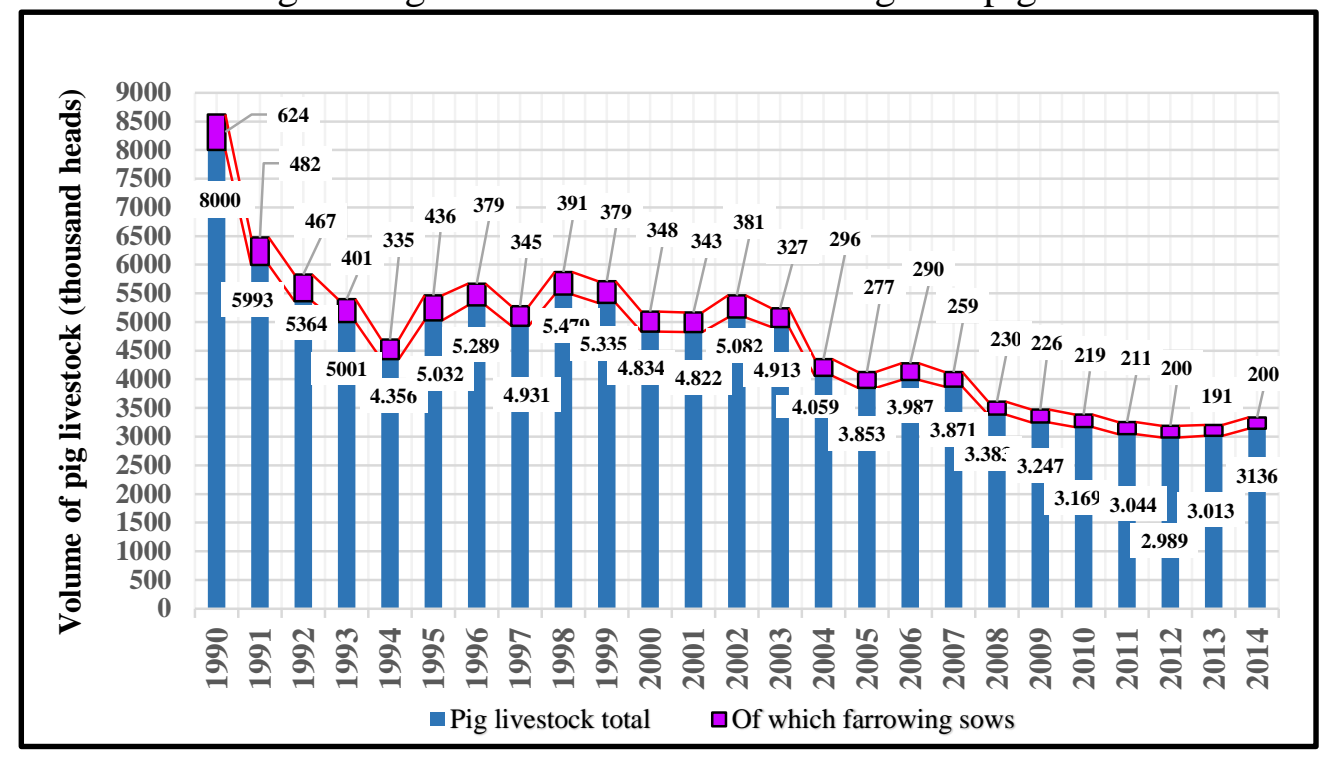

Table 1: Changes in Hungarian pig livestock between 1990 and 2014 (thousand heads) Source: http://www.ksh.hu/docs/hun/xstadat/xstadat_eves/i_oma003.html

The general trend of declining pig stock over the years affected the stock of farrowing sows as well. In 1994, the number of farrowing sows was only 335 thousand, which increased to 381 thousand by the end of 2002, but was still only $39 \%$ of the 1990 figure. Then it started declining again and stood at 296 thousand in 2004, and then by 2013, dropped below 200 thousand which means a $70 \%$ decrease compared to the base year and gives reason for great concern. The total figure of pig livestock in 2014 is nearly 1.220 million heads lower and shows a drastic 28\% decline compared to the 1994 figures. Admittedly, in 2002, the stock showed a modest 17\% increase on the 1994 numbers. As a result of the market changes, both pig and farrowing sow livestock showed a steady decline from 2003 onwards (Kapronczai 2003).

According to the EUROSTAT data, Hungary's pig livestock numbered 3.044 million heads in December 2011, and showed a nearly 125 thousand drop compared to the figures of a year earlier. The number of sows was 8 thousand lower. The decline continued in 2012 with a further drop of 55 thousand heads of pigs and 11 thousand of farrowing sows. Although pig livestock reached 3.013 million by 2013, with a meagre increase of 24 thousand heads, sow stock showed a further decline by 9 thousand. In the course of the past two decades, the volume of pig livestock fell by $40 \%$, while 
the volume of sows shows a drop of $32 \%$ if we compare the 2014 figures to the base year of 1990 .

According to the public figures issued by the Central Statistical Office, 3.095 million pig livestock was recorded in Hungary on 1 June 2014, which shows a slight $(7 \%)$ increase compared to the figure of the previous year. The growth was $8.5 \%$ with private farmers (841 thousand heads) and $6.5 \%$ with business organisations (2.254 million heads). The stock of farrowing sows increased by $3.6 \%$ to 200 thousand heads compared to the figure of June 2013. (Retrieved from: https://sertesinfo.aki.gov.hu)

From the point of the stock's reproductive capacity the decisive factor is the number and the state of performing capacity of the livestock. However, the prevailing trends characterising the domestic pig livestock are in contrast with the guiding principles adapted in the other EU member states with significant pig farming capacity (Kralovánszky, 2009).

Due to the constant problems of uncertainty, financial losses and missed incomes many private farmers gave up pig breeding and pork production. Currently, the decline seems to continue and this could lead to the complete disintegration of the pig farming sector seriously affecting the whole food industry and the industrial sectors (fodder production, transport, construction) supplying it. The main reason for the decline in pig livestock is the steady decrease of profitability in the sector which directly affects production.

To satisfy the demand of the local, population a pig livestock of 4.5 million would be needed with a further 2 million heads to regain the lost export markets. It must be noted that Hungarian pork products are of high quality and in demand on the world market therefore it is very important to win back our former positions. The contribution of meat export to the national economy greatly depends on the volume and production capacity of the pig farming sector. In case the market situation stays adverse for export, a further decline in the volume of Hungarian pig livestock can be predicted (The Pig Lobby, 2011).

A significant part of pig farming businesses in Hungary do not own farmland and is unable to produce the fodder they require. There are two causes making management of the businesses difficult to sustain. One is to provide adequate quantity of fodder which is a constant worry as in pig farming it accounts for 55-70\% of total expenses and the growing prices on the corn market work against efficiency of production. The other problem is the safe deposition of liquid manure generated during production since the utilisation of manure as biogas is in a very embryonic stage in Hungary, and due to the low purchase price, is not really encouraging to farmers (Nagy \& Aliczki, 2014). 
According to the findings of Pop et al. (2009), the biggest problems in pig farming are caused by the slow weight gain, low utilisation level of fodder, overextended fattening time, and the costs of sow rotation and labour. Increased efficiency could be based on the introduction of modern pig farming technologies and a careful selection of breeding species (Pop \& Potori, 2009).

\section{Conclusion}

The effects of European Union rules and regulations of the pig sector is deeply affected. It is therefore important that the pig entrepreneurs with the relevant European Union standards must be aware that the new current tender offer will be achieved, thus a realistic chance of achieving the successful tender and European Union funds. According to the nation's economic aspects of strategic importance, as some titles in the pig sector enjoy the subsidies. The development is an important condition for Hungary to weight and income-generating ability of the business to improve pig, so the government has launched a swine program.

In our high-paced world the innovative edge is gaining an ever greater role. Its importance is further increased by the relative abundance of capital; producers and customers alike are willing to pay for novelties. The increase in demand and the globalised sales opportunities led to the fact that successful innovations result in higher rates of profit. On the other hand, the implementation of successful innovations have become more and more expensive since sophisticated technical solutions need sizeable financial sources and global sales require large volume investments. A further consequence of these rapid developments is that the time available to exploit the innovative edge has become shorter: in the wake of a novelty comes an even newer one almost immediately. In their works, Martin and Schmann (1998) emphasize that the business world has to adapt to globalisation. The global economy incorporates the labour market as well; there is no locally based job that could be declared secure. Eventually, the most important factor is still the absolute cost advantage.

Labour is one of the most important resources of all regions and countries. Workers' professional knowledge, skills and experience are vital to the operation of the technical means available, to the formation of a common vision about the future and the achievement of goals. Every member of the population must be made available and secured the highest possible quality of life according to their potentials (Vinkler, 2013).

\section{References:}

1. Agrárgazdasági Kutató Intézet Sertés Információs Rendszer.

2. Húsfogyasztás: Egy főre jutó hús fogyasztás alakulása Magyarországon. 
3. https://sertesinfo.aki.gov.hu/publikaciok/kuldes/a:638/Az+egy+f\%C5 $\% 91$ re+jut $\%$ C3\%B3+h\%C3\%BAsfogyaszt\%C3\%A1s+alakul\%C3\% A1sa+Magyarorsz $\%$ C3\%A1gon

4. Agrárgazdasági Kutató Intézet Sertés Információs Rendszer.

5. https://sertesinfo.aki.gov.hu/publikaciok/kuldes/a:935/N\%C5\%91tt+ Magyarorsz\%C3\%A1g+sert\%C3\%A9s\%C3\%A1llom\%C3\%A1nyaAKII. Nőtt Magyarország sertésállománya

6. Buday S. A. (2001): „Agrárpolitika-Vidékpolitika”.A magyar agrárgazdaság és az Európai Unió. Budapest-Pécs: Dialóg Campus Kiadó. p 10

7. Európai Bizottság, 2009a

8. Kapronczai I. (2003): A magyar agrárgazdaság a rendszerváltástól az Európai Unióig. Szaktudás Kiadó Ház, Budapest, 92-94 p.

9. Kartali J. (2008): A hazai élelmiszer-kikereskedelem struktúrája, különös tekintettel a kistermelök értékesítési lehetöségeire. Aki Tanulmány. Budapest. (Popp J., Potori N. szerk.) p 55 p.

10. Kralovánszky U. P. (2009): Mi történik velünk: Magyar Állattenyésztés (1918-2008). Állattenyésztés és Takarmányozás Vol.58 (No.1) pp. 3-5,

11. http://stats.oecd.org/wbos/viewhtml.aspx?QueryName=237\&QueryT ype $=$ View\&Lang=en.

12. KSH:

http://www.ksh.hu/docs/hun/xstadat/xstadat_eves/i_oma003.html

13. Nagy L., Aliczki K., (2014.10.02-03): A sertéshús termelés versenyképessége Magyarországon. LVI. Georgikon Napok, 56 Georgikon Scientific Conference, Budapest pp 266-275.

14. http://napok.georgikon.hu/cikkadatbazis/cikkek-2012/doc_view/194nagy-laszlo-

15. aliczki-katalin-kornelia-a-serteshustermeles-versenykepessegemagyarorszagon.

16. Popp J., Potori N.. (2009): A föbb állattenyésztési ágazatok helyzete. Agrárgazdasági Tanulmányok. Agrárgazdasági Kutató Intézet, 2009.3. szám, Budapest, pp 49-56, 111,73

17. Popp J. (2004): Az EU közös agrárpolitikájának elmélete és nemzetközi mozgástere. Európai Agrárpolitikai Kft. Budapest, pp 40-41.238-247.

18. Sántha A. (1999): Allattenyésztésünk helyzete és EU-konform fejlesztésének koncepciója. Kerekes S. szerk. Környezetbarát Mezőgazdálkodás. Magyar Tudományos Akadémia, Budapest. (Mühely Tanulmány) p 61.

19. Sertés lobbi (2011): A sertéságazat helyzete és a kibontakozás lehetséges irányai Magyarországon (2011.03.26.) p 4,10 www. Sertes_Lobbi_szakmai_anyag 
20. Varga T., Tunyoginé Nechay V., Mizik T.(2007): A mezőgazdasági árképzés elméleti alapjai és hazai gyakorlata. Agrárgazdasági Tanulmányok. Agrárgazdasági Kutató Intézet,2007.2. szám, Budapest, p 85-89,92-93.

21. Vinkler B. (2006): A kis- és középvállalkozások helyzete napjainkban. „Tudomány Ünnepe Konferencia” Dunaújvárosi Föiskola 2005. november 21-25. Dunaújvárosi Főiskola Közleményei XXVII/II. (2005) 639-642 pp.

22. Vinkler B. (2013): Gondolatok a hazai mezőgazdasági vállalkozások helyzetéröl. Regionális Földrajzi Tanulmányok. Abonyiné Dr. Palotás Jolán 70. születésnapja tiszteletére. Egyesület Közép-Európai Kutatására. Szeged 2013.05.24. ISSN 2062-3712 ISBN: 978-96389724-2-2. pp. 91-98. 